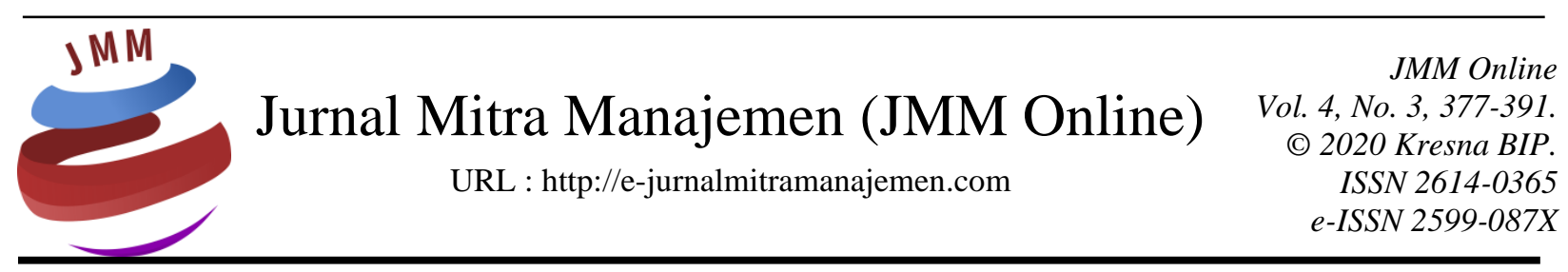

\title{
PENGARUH SISTEM PERPAJAKAN, PELAYANAN PERPAJAKAN, SANKSI PAJAK DAN KESADARAN WAJIB PAJAK TERHADAP KEPATUHAN DAN KEPUTUSAN MEMBAYAR PAJAK KENDARAAN BERMOTOR PADA SAMSAT BANJARMASIN I
}

\author{
Adi Rahman 1), Siti Paujiah 2), Anthonius J. Karsudjono ${ }^{3)}$, Laila Najmi ${ }^{4)}$ \\ Sekolah Tinggi Ilmu Ekonomi Pancasetia Banjarmasin
}

INFORMASI ARTIKEL

Dikirim : 09 Maret 2020

Revisi pertama : 26 Maret 2020

Diterima : 28 Maret 2020

Tersedia online : 30 Maret 2020

Kata Kunci : Sistem Perpajakan, Pelayanan Perpajakan, Sanksi Pajak, Kesadaran Wajib Pajak, Kepatuhan dan Keputusan

Email : adirahman546@gmail.com ${ }^{1)}$, jiahmanis8@gmail.com ${ }^{2}$, tonimbbm@yahoo.com ${ }^{3)}$, lailanajmi20@gmail.com ${ }^{4)}$

\section{ABSTRAK}

Penelitian ini bertujuan untuk mengetahui dan menganalisis pengaruh secara simultan, parsial dan dominan antara sistem perpajakan, pelayanan perpajakan, sanksi pajak dan kesadaran wajib pajak terhadap kepatuhan dan keputusan membayar pajak kendaraan bermotor pada Samsat Banjarmasin I. Metode penelitian menggunakan survey analitik dengan pendekatan Cross Sectional. Sampel menggunakan teknik accidental sampling sebanyak 100 orang masyarakat yang membayarkan pajak kendaraan bermotor. Teknik pengumpulan data menggunakan kuesioner dan dianalisis menggunakan uji regresi linear berganda, uji $F$ dan uji $t$ dengan tingkat kemaknaan 95\% $(\alpha=0,05)$. Ada pengaruh signifikan secara simultan dan parsial antara sistem perpajakan, pelayanan perpajakan, sanksi pajak dan kesadaran wajib pajak terhadap kepatuhan dan keputusan membayar pajak kendaraan bermotor pada Samsat Banjarmasin I. Pelayanan perpajakan merupakan variabel yang memiliki pengaruh dominan terhadap kepatuhan membayar pajak kendaraan bermotor pada Samsat Banjarmasin I dan kepatuhan merupakan variabel yang memiliki pengaruh dominan terhadap keputusan membayar pajak kendaraan bermotor pada Samsat Banjarmasin I. 


\section{PENDAHULUAN \\ Latar Belakang}

Indonesia merupakan negara yang memiliki berbagai kekayaan sumber daya, tetapi saat ini Indonesia belum mampu memaksimalkan sumber daya tersebut. Salah satu sumber pendapatan negara terbesar adalah penerimaan pajak. Pajak yang dihasilkan oleh pemerintah digunakan untuk pembangunan nasional baik pembangunan fisik maupun non fisik. Hal ini dilakukan untuk meningkatkan kesejahteraan masyarakat karena ajak memiliki peran dalam pembangunan nasional. Pajak dapat dirasakan manfaatnya secara langsung atau pun tidak secara langsung oleh masyarakat. Ada pun manfaat yang dirasakan dari pajak adalah fasilitas pendidikan, fasilitas transportasi, fasilitas kesehatan sarana dan prasarana umum. Untuk mencukupi semua kebutuhan pembangunan nasional, negara membutuhkan peningkatan dalam penerimaan pajak (Waluyo, 2010).

Jumlah penerimaan pajak selalu lebih rendah dari jumlah rencana yang diharapkan, ini menunjukan bahwa masih kurangnya kesadaran wajib pajak. Seperti yang dilansir dari laman pajak.go.id realisasi jumlah penarikan piutang pajak yang belum mencapai target. Masih kurangnya Kesadaran Wajib Pajak menjadi sebab tidak tercapainya target penerimaan pajak tahun 2019. Jumlah persentase penerimaan pajak dari tahun 2019 masih kurang dari target $80 \%$ penerimaan pendapatan pajak yang diharapkan oleh pemerintah.

Pemerintah mampu merealisasikan penerimaan pajak senilai $\mathrm{Rp}$ 1.255.560.258.905 pada 2016 dengan bantuan tax amnesty yang mengakibatkan warga Negara Indonesia (WNI) banyak menarik dana mereka di luar negeri ke Indonesia kembali. Jumlah tersebut mencapai 90,8\% dari yang ditargetkan dalam Anggaran Penerimaan dan Belanja Negara Perubahan (APBNP) 2015 yang tercatat Rp 1.383.276.730.161. Selanjutnya pajak secara keseluruhan per 31 Desember 2019 mencapai $\mathrm{Rp}$ 942.253.250.354 atau sebesar 71,1\% dari target penerimaan pajak APBN Perubahan 2019 sebesar Rp 1.325.223.222.455.

Berdasarkan data Badan Keuangan Daerah (Bakeuda) Provinsi Kalsel realisasi penerimaan pajak kendaraan bermotor (PKB) pada UPPD/SAMSAT Banjarmasin 1 hingga September 2019 sebesar Rp74.316.912.055,00 atau mengalami pertumbuhan 6,84\% dibandingkan realisasi tahun 2018 sebesar Rp69.556.615.925,00, sedangkan realisasi pada UPPD/SAMSAT Banjarmasin 2 hingga September 2019 realisasi sebesar Rp96.558.782.150,00 atau mengalami pertumbuhan 8,13\% dibandingkan realisasi tahun 2018 sebesar Rp89.296.843.485,00.

Berbagai kebijakan dan terobosan dilakukan Pemerintah Provinsi Kalsel di bawah kepemimpinan Gubernur Sahbirin Noor dan Wakil Gubernur Rudy Resnawan dalam meningkatkan pendapatan asli daerah (PAD) dari sektor pajak kendaraan bermotor (PKB). Inovasi dan kreatifitas yang dilakukan seperti layanan Samsat Keliling (SAMKEL), Drive Thru, Jemput Antar dan Samsat Corner Duta Mall yang melayani pembayaran secara online dan lain sebagainya, berhasil meningkatkan realisasi pendapatan.

Meningkatnya realisasi PKB di UPPD/SAMSAT Banjarmasin 1 dan 2 karena wajib pajak (WP) memenuhi kewajibannya ditunjang oleh keberadaan layanan konvensional yang mudah, tidak rumit dan cepat. Kebijakan dalam mempermudah 
akses pelayanan kepada wajib pajak terus ditingkatkan, seperti beberapa titik layanan Samsat Keliling (SAMKEL), Drive Thru, Jemput Antar dan Samsat Corner Duta Mall yang melayani pembayaran secara online.

Mengenai komponen pendapatan Bea Balik Nama Kendaraan Bermotor (BBNKB) khususnya kendaraan bermotor baru, pergerakannya sedikit lambat yaitu tumbuh hanya 3,65\% dibanding September 2018 lalu. Sebagai perbandingan daerah lainnya, kisaran pertumbuhan kendaraan bermotor baru antara 7\%-15\%.

Berdasarkan adanya perbedaan hasil penelitian tersebut, maka penelitian ini bertujuan untuk mengetahui dan menganalisis pengaruh secara simultan antara sistem perpajakan, pelayanan perpajakan, sanksi pajak dan kesadaran wajib pajak terhadap kepatuhan dan keputusan membayar pajak kendaraan bermotor pada Samsat Banjarmasin I.

\section{Rumusan Masalah}

1) Apakah sistem perpajakan, pelayanan perpajakan, sanksi pajak dan kesadaran wajib pajak berpengaruh secara simultan terhadap kepatuhan dan keputusan membayar pajak kendaraan bermotor pada Samsat Banjarmasin I?

2) Apakah sistem perpajakan, pelayanan perpajakan, sanksi pajak dan kesadaran wajib pajak berpengaruh secara parsial terhadap kepatuhan dan keputusan membayar pajak kendaraan bermotor pada Samsat Banjarmasin I?

3) Variabel manakah antara sistem perpajakan, pelayanan perpajakan, sanksi pajak dan kesadaran wajib pajak berpengaruh secara dominan terhadap kepatuhan dan keputusan membayar pajak kendaraan bermotor pada Samsat Banjarmasin I?

\section{Tujuan Penelitian}

1) Mengetahui dan menganalisis pengaruh secara simultan antara sistem perpajakan, pelayanan perpajakan, sanksi pajak dan kesadaran wajib pajak terhadap kepatuhan dan keputusan membayar pajak kendaraan bermotor pada Samsat Banjarmasin I.

2) Mengetahui dan menganalisis pengaruh secara parsial antara sistem perpajakan, pelayanan perpajakan, sanksi pajak dan kesadaran wajib pajak terhadap kepatuhan dan keputusan membayar pajak kendaraan bermotor pada Samsat Banjarmasin I.

3) Mengetahui dan menganalisis pengaruh secara dominan antara sistem perpajakan, pelayanan perpajakan, sanksi pajak dan kesadaran wajib pajak terhadap kepatuhan dan keputusan membayar pajak kendaraan bermotor pada Samsat Banjarmasin I.

\section{KAJIAN PUSTAKA \\ Konsep Pajak}

Pajak merupakan iuran yang dipungut oleh Negara baik oleh pemerintah pusat maupun pemerintah daerah berdasarkan atas undang-undang serta aturan pelaksanaan pemungutan pajak mengisyaratkan adanya alih dana dari sektor swasta (Wajib Pajak yang membayar pajak) ke sektor negara (pemungut pajak pemerintah) dan diperuntukan bagi keperluan pembiyaan umum pemerintah dalam rangka menjalankan fungsi pemerintahan, baik rutin maupun pembangunan (Aristanti, 2018). 


\section{Konsep Wajib Pajak}

Wajib Pajak adalah orang pribadi atau badan yang melakukan kewajiban perpajakan yang telah diatur didalam undang-undang perpajakan. Wajib Pajak sangatlah memegang peranan yang sangat penting bagi kelancaran Sistem dan peraturan perundang-undangan perpajakan. Menurut Undang-undang No.28 Tahun 2007 Pasal 1 ayat (1) Tentang Tata Cara Perpajakan bahwa yang dimaksud dengan Wajib Pajak (tax payer) adalah orang pribadi atau badan yang menurut ketentuan peraturan perundang-undangan perpajakan ditentukan untuk melakukan kewajiban perpajakan, termasuk pemungut pajak atau pemotong pajak tertentu (Resmi, 2019).

\section{Konsep Pengetahuan Perpajakan}

Menurut Kamus Bahasa Indonesia (2018) "pengetahuan berarti segala sesuatu yang diketahui; kepandaian: atau segala sesuatu yang diketahui berkenaan dengan hal (mata pelajaran)".

Pengetahuan perpajakan adalah segala sesuatu atau informasi yang diketahui Wajib Pajak dalam peraturan perpajakan baik itu soal tarif pajak berdasarkan UndangUndang untuk dilaksanakan sebagai hak dan kewajiban yang akan mereka serahkan maupun manfaat pajak yang digunakan sebagai kepentingan umum. Serta dapat mengaplikasikan yang seharusnya dilakukan oleh Wajib Pajak (Resmi, 2019).

\section{Konsep Sanksi Pajak}

Sanksi berasal dari bahasa Belanda yaitu Sanctie yang artinya ancaman hukuman, merupakan suatu alat pemaksa guna ditaatinya suatu kaidah, UndangUndang misalnya sanksi terhadap pelanggaran suatu Undang-Undang (Rahayu, 2016).

Sanksi perpajakan dapat dikatakan jaminan peraturan perundangundangan perpajakan (norma perpajakan) akan dituruti/ditaati/dipatuhi oleh wajib pajak untuk tidak melakukan tindakan melanggar norma perpajakan. Sanksi pajak terjadi karena pelanggaran terhadap peraturan perundang-undangan perpajakan khususnya dalam ketentuan umum atau atau tata cara perpajakan (Resmi, 2019).

\section{Konsep Sosialisasi Perpajakan}

Menurut Rahayu (2016) "Sosialisasi perpajakan adalah upaya yang dilakukan oleh Dirjen Pajak untuk memberikan sebuah pengetahuan kepada masyarakat dan khususnya Wajib Pajak agar mengetahui tentang segala hal mengenai perpajakan baik peraturan maupun tata cara perpajakan melalui metode-metode yang tepat."

\section{Konsep Kepatuhan Pajak}

Soemarso (2016) mengemukakan bahwa prinsip pajak yang diterima secara luas memiliki tujuan yang ingin dicapai yaitu kepatuhan sukarela. Kepatuhan sukarela merupakan tulang punggung self assessment system di mana Wajib Pajak bertanggung jawab menetapkan sendiri kewajiban pajaknya dan kemudian secara akurat dan tepat waktu membayar dan melaporkan pajak tersebut. Ismawan juga menyebutkan bahwa kepatuhan sebagai fondasi self assessment system dapat dicapai apabila elemenelemen kunci telah diterapkan secara efektif. Elemen-elemen kunci tersebut adalah sebagai berikut: 
1. Program pelayanan yang baik kepada Wajib Pajak.

2. Prosedur yang sederhana dan memudahkan Wajib Pajak.

3. Program pemantauan kepatuhan dan verifikasi yang efektif.

4. Pemantapan law enforcement secara tegas dan adil.

\section{METODE PENELITIAN}

\section{Tempat, Waktu dan Subjek Penelitian}

Jenis penelian ini menggunakan kuantitatif dengan metode survey analitik dengan pendekatan Cross Sectional. Penelitian ini dilakukan pada Samsat Banjarmasin I pada bulan Februari 2020 terhadap 100 orang masyarakat yang melakukan pembayaran pajak kendaraan bermotor dengan menggunakan teknik accidental sampling .

\section{Teknik Pengumpulan Data}

Teknik pengumpulan data menggunakan data primer yang berasal dari hasil kuesioner tertutup dengan menggunakan skala Likert yang dibagikan kepada responden yaitu 100 orang masyarakat yang melakukan pemabyaran pajak kendaraan bermotor pada Samsat Banjarmasin I.

\section{Teknik Analisis Data}

Hasil kuesioner dianalisis menggunakan uji regresi yang terdiri dari uji asumsi klasik, uji regresi linier berganda, uji $\mathrm{F}$ dan uji t dengan tingkat kemaknaan 95\% $(\alpha=0,05)$, sedangkan untuk menganalisis pengaruh dominan, peneliti melihat berdasarkan nilai Beta pada hasil uji t dan besarnya pengaruh dilihat dari nilai $\mathrm{R}^{2}$ pada tabel koefesien determinasi.

\section{HASIL PENELITIAN DAN PEMBAHASAN}

\section{Uji Asumsi Klasik Pengaruh X-Z}

a. Uji Normalitas

Hasil uji normalitas pengaruh sistem perpajakan, pelayanan perpajakan, sanksi pajak dan kesadaran wajib pajak berpengaruh secara dominan terhadap kepatuhan membayar pajak kendaraan bermotor pada Samsat Banjarmasin I dengan Kolmogorov-Smirnov test dapat dilihat pada Tabel 1.

Tabel 1. Kolmogorov-Smirnov Test Pengaruh $\mathrm{X}$ terhadap $\mathrm{Z}$

\begin{tabular}{|l|l|l|l|l|}
\hline No. & Variabel & Kolmogorov-Smirnov Z & Asymp. Sig. (2-tailed) & Keterangan \\
\hline 1 & $\mathrm{X} 1$ & 1,170 & 0,001 & Normal \\
\hline 2 & $\mathrm{X} 2$ & 1,000 & 0,000 & Normal \\
\hline 3 & $\mathrm{X} 3$ & 0,895 & 0,009 & Normal \\
\hline 4 & $\mathrm{X} 4$ & 0,959 & 0,000 & Normal \\
\hline
\end{tabular}

Sumber : Hasil Penelitian, diolah (2020)

Berdasarkan Tabel 1 menunjukkan bahwa data terdistribusi normal jika Asymp. Sig. (2-tailed) < 0,05. Hal tersebut menyatakan bahwa nilai Asymp. Sig. (2-tailed) variabel sistem perpajakan $\left(\mathrm{X}_{1}\right)$ tidak mengalami gangguan distribusi normal dan memenuhi asumsi normalitas karena 0,001 <0,050, nilai Asymp. Sig. (2-tailed) variabel pelayanan perpajakan $\left(\mathrm{X}_{2}\right)$ tidak mengalami gangguan 
distribusi normal dan memenuhi asumsi normalitas karena 0,001 $<0,050$, nilai Asymp. Sig. (2-tailed) variabel sanksi pajak $\left(\mathrm{X}_{3}\right)$ tidak mengalami gangguan distribusi normal dan memenuhi asumsi normalitas karena $0,009<0,050$ dan nilai Asymp. Sig. (2-tailed) variabel kesadaran wajib pajak $\left(\mathrm{X}_{4}\right)$ tidak mengalami gangguan distribusi normal dan memenuhi asumsi normalitas karena 0,000 < 0,050 .

b. Uji Multikoliniaritas

Adapun hasil uji Multikoliniaritas dalam penelitian ini dapat dilihat pada tabel berikut ini:

Tabel 2. Hasil Uji Multikoliniaritas

\begin{tabular}{|c|c|c|}
\hline \multicolumn{3}{|c|}{ Coefficients $^{a}$} \\
\hline \multirow[t]{2}{*}{ Model } & \multicolumn{2}{|c|}{ Collinearity Statistics } \\
\hline & Tolerance & VIF \\
\hline (Constant) & & \\
\hline$x 1$ & .113 & 8.816 \\
\hline$x 2$ & .062 & 6.242 \\
\hline$x 3$ & .054 & 8.686 \\
\hline$\times 4$ & .083 & 2.107 \\
\hline
\end{tabular}

lependent Variable: $z$

Sumber : Hasil Penelitian, diolah (2020)

Berdasarkan tabel tersebut diketahui bahwa angka tolerance mempunyai nilai lebih dari $10 \%$ dan nilai VIF tidak lebih dari 10 yang berarti tidak terjadi Multikoliniaritas antar variabel bebas tersebut.

c. Uji Heteroskedastisitas

Heteroskedastisitas dapat diketahui dengan uji Glester. Jika probabilitas masing-masing variabel independen $>0,05$ maka disimpulkan tidak terjadi heteroskedastisitas dalam model regresi. Hasil uji glejser dapat dilihat di bawah ini:

Tabel 3. Hasil Uji Heteroskedastisitas

\begin{tabular}{|l|l|l|}
\hline Variabel & Nilai Signifikan & Keterangan \\
\hline X1 & 0,221 & Tidak Terjadi Heteroskedastisitas \\
\hline X2 & 0,478 & Tidak Terjadi Heteroskedastisitas \\
\hline X3 & 0,089 & Tidak Terjadi Heteroskedastisitas \\
\hline X4 & 0,422 & Tidak Terjadi Heteroskedastisitas \\
\hline Z & 0,490 & Tidak Terjadi Heteroskedastisitas \\
\hline
\end{tabular}

Sumber : Hasil Penelitian, diolah (2020)

Berdasarkan pada Tabel 3 dijelaskan bahwa varibel sistem perpajakan $\left(\mathrm{X}_{1}\right)$, pelayanan perpajakan $\left(\mathrm{X}_{2}\right)$, sanksi pajak $\left(\mathrm{X}_{3}\right)$, dan kesadaran wajib pajak $\left(\mathrm{X}_{4}\right)$ tidak terjadi heteroskedastisitas karena nilai signifikasi antara variabel independen dengan absolute residual lebih dari 0,05.

\section{Uji Asumsi Klasik Pengaruh X dan Z terhadap Y}

a. Uji Normalitas

Hasil uji normalitas pengaruh sistem perpajakan, pelayanan perpajakan, sanksi pajak dan kesadaran wajib pajak berpengaruh secara dominan terhadap kepatuhan dan keputusan membayar pajak kendaraan bermotor pada Samsat Banjarmasin I dengan Kolmogorov-Smirnov test dapat dilihat pada Tabel 4. 
Tabel 4. Kolmogorov-Smirnov Test Pengaruh $\mathrm{X}$ dan $\mathrm{Z}$ terhadap $\mathrm{Y}$

\begin{tabular}{|l|l|l|l|l|}
\hline No. & Variabel & Kolmogorov-Smirnov Y & Asymp. Sig. (2-tailed) & Keterangan \\
\hline 1 & $\mathrm{X}_{1}$ & 1,170 & 0,001 & Normal \\
\hline 2 & $\mathrm{X}_{2}$ & 1,000 & 0,000 & Normal \\
\hline 3 & $\mathrm{X}_{3}$ & 0,895 & 0,000 & Normal \\
\hline 4 & $\mathrm{X}_{4}$ & 0,959 & 0,000 & Normal \\
\hline 5 & $\mathrm{Z}$ & 0,886 & 0,000 & Normal \\
\hline
\end{tabular}

Sumber : Hasil Penelitian, diolah (2020)

Berdasarkan Tabel 4 menunjukkan bahwa data terdistribusi normal jika Asymp. Sig. (2-tailed) < 0,05. Hal tersebut menyatakan bahwa nilai Asymp. Sig. (2-tailed) variabel sistem perpajakan $\left(\mathrm{X}_{1}\right)$ tidak mengalami gangguan distribusi normal dan memenuhi asumsi normalitas karena 0,001 <0,050, nilai Asymp. Sig. (2-tailed) variabel pelayanan perpajakan $\left(\mathrm{X}_{2}\right)$ tidak mengalami gangguan distribusi normal dan memenuhi asumsi normalitas karena 0,001 $<0,050$, nilai Asymp. Sig. (2-tailed) variabel sanksi pajak $\left(\mathrm{X}_{3}\right)$ tidak mengalami gangguan distribusi normal dan memenuhi asumsi normalitas karena $0,000<0,050$, nilai Asymp. Sig. (2-tailed) variabel kesadaran wajib pajak $\left(\mathrm{X}_{4}\right)$ tidak mengalami gangguan distribusi normal dan memenuhi asumsi normalitas karena 0,000 < 0,050 dan nilai Asymp. Sig. (2-tailed) variabel kepatuhan (Z) tidak mengalami gangguan distribusi normal dan memenuhi asumsi normalitas karena $0,000<$ 0,050 .

b. Uji Multikoliniaritas

Adapun hasil uji Multikoliniaritas dalam penelitian ini dapat dilihat pada tabel berikut ini:

Tabel 5. Hasil Uji Multikoliniaritas

Coefficients $^{a}$

\begin{tabular}{|c|l|c|}
\hline \multirow{2}{*}{ Model } & \multicolumn{2}{|l|}{ Collinearity Statistics } \\
\cline { 2 - 3 } & Tolerance & VIF \\
\hline (Constant) & & \\
x1 & .101 & 9.857 \\
x2 & .049 & .579 \\
& .044 & 2.853 \\
& .074 & 3.594 \\
& .025 & 9.837 \\
\hline
\end{tabular}

lependent Variable: $y$

Sumber : Hasil Penelitian, diolah (2020)

Berdasarkan tabel tersebut diketahui bahwa angka tolerance mempunyai nilai lebih dari $10 \%$ dan nilai VIF tidak lebih dari 10 yang berarti tidak terjadi Multikoliniaritas antar variabel bebas tersebut.

c. Uji Heteroskedastisitas

Heteroskedastisitas dapat diketahui dengan uji Glester. Jika probabilitas masing-masing variabel independen $>0,05$ maka disimpulkan tidak terjadi heteroskedastisitas dalam model regresi. Hasil uji glejser dapat dilihat di bawah ini: 
Tabel 6. Hasil Uji Heteroskedastisitas

\begin{tabular}{|l|l|l|}
\hline Variabel & Nilai Signifikan & Keterangan \\
\hline $\mathrm{X}_{1}$ & 0,081 & Tidak Terjadi Heteroskedastisitas \\
\hline $\mathrm{X}_{2}$ & 0,074 & Tidak Terjadi Heteroskedastisitas \\
\hline $\mathrm{X}_{3}$ & 0,385 & Tidak Terjadi Heteroskedastisitas \\
\hline $\mathrm{X}_{4}$ & 0,221 & Tidak Terjadi Heteroskedastisitas \\
\hline $\mathrm{Z}$ & 0,485 & Tidak Terjadi Heteroskedastisitas \\
\hline
\end{tabular}

Sumber : Hasil Penelitian, diolah (2020)

Berdasarkan pada Tabel 6 dijelaskan bahwa varibel sistem perpajakan $\left(\mathrm{X}_{1}\right)$, pelayanan perpajakan $\left(\mathrm{X}_{2}\right)$, sanksi pajak $\left(\mathrm{X}_{3}\right)$, kesadaran wajib pajak $\left(\mathrm{X}_{4}\right)$ dan kepatuhan $(\mathrm{Z})$ tidak terjadi heteroskedastisitas karena nilai signifikasi antara variabel independen dengan absolute residual lebih dari 0,05.

\section{Analisa Regresi X-Z}

Berdasarkan hasil pengolahan data dengan bantuan program SPSS Versi 18 untuk analisa regresi sederhana diperoleh hasil sebagai berikut:

Coefficients $^{a}$

Tabel 7. Hasil Analisa Regresi

\begin{tabular}{|c|c|c|c|c|c|c|}
\hline \multirow{2}{*}{\multicolumn{2}{|c|}{ Model }} & \multicolumn{2}{|c|}{ Unstandardized Coefficients } & $\begin{array}{l}\text { Standardized } \\
\text { Coefficients }\end{array}$ & \multirow[b]{2}{*}{$t$} & \multirow[b]{2}{*}{ Sig. } \\
\hline & & $\mathrm{B}$ & Std. Error & Beta & & \\
\hline \multirow[t]{5}{*}{1} & (Constant) & -.227 & .245 & & -.925 & .357 \\
\hline & $x 1$ & .192 & .057 & .162 & 3.349 & .001 \\
\hline & $x 2$ & .336 & .067 & .330 & 5.036 & .000 \\
\hline & $x 3$ & .324 & .070 & .323 & 4.602 & .000 \\
\hline & $x 4$ & 201 & .059 & .193 & 3.416 & .001 \\
\hline
\end{tabular}

a. Dependent Variable: $z$

Sumber : Hasil Penelitian, diolah (2020)

Adapun penjelasan uraian dari persamaan regresi tersebut adalah:

$\mathrm{Z}=-0,2227+0,192\left(\mathrm{X}_{1}\right)+0,336\left(\mathrm{X}_{2}\right)+0,324\left(\mathrm{X}_{3}\right)+0,201\left(\mathrm{X}_{4}\right)+\mathrm{e}$

Dengan bunyi persamaan sebagai berikut:

a. Persamaan Regresi Sistem Perpajakan $\left(\mathrm{X}_{1}\right)$

Koefesien regresi variabel sistem perpajakan $\left(\mathrm{X}_{1}\right)$ sebesar 0,192 artinya jika sistem perpajakan $\left(\mathrm{X}_{1}\right)$ mengalami kenaikan sebesar $1 \%$, maka kepatuhan membayar pajak kendaraan bermotor pada Samsat Banjarmasin I akan mengalami kenaikan sebesar $19,2 \%$.

b. Persamaan Regresi Pelayanan perpajakan $\left(\mathrm{X}_{2}\right)$

Koefesien regresi variabel Pelayanan perpajakan $\left(\mathrm{X}_{2}\right)$ sebesar 0,336 artinya jika Pelayanan perpajakan $\left(\mathrm{X}_{2}\right)$ mengalami kenaikan sebesar 1\%, maka kepatuhan membayar pajak kendaraan bermotor pada Samsat Banjarmasin I akan mengalami kenaikan sebesar 33,6\%.

c. Persamaan Regresi Sanksi perpajakan $\left(\mathrm{X}_{3}\right)$

Koefesien regresi variabel sanksi perpajakan $\left(\mathrm{X}_{3}\right)$ sebesar 0,324 artinya jika sanksi perpajakan $\left(\mathrm{X}_{3}\right)$ mengalami kenaikan sebesar $1 \%$, maka kepatuhan 
membayar pajak kendaraan bermotor pada Samsat Banjarmasin I akan mengalami kenaikan sebesar $32,4 \%$.

d. Persamaan Regresi Kesadaran Wajib Pajak $\left(\mathrm{X}_{4}\right)$

Koefesien regresi variabel sanksi perpajakan $\left(\mathrm{X}_{4}\right)$ sebesar 0,201 artinya jika sanksi perpajakan $\left(\mathrm{X}_{4}\right)$ mengalami kenaikan sebesar $1 \%$, maka kepatuhan membayar pajak kendaraan bermotor pada Samsat Banjarmasin I akan mengalami kenaikan sebesar $20,1 \%$.

\section{Analisa Regresi X,Z-Y}

Berdasarkan hasil pengolahan data dengan bantuan program SPSS Versi 18 untuk analisa regresi sederhana diperoleh hasil sebagai berikut:

Coefficients $^{\mathrm{a}}$

Tabel 8. Hasil Analisa Regresi

\begin{tabular}{|c|c|c|c|c|c|c|}
\hline \multirow{2}{*}{\multicolumn{2}{|c|}{ Model }} & \multicolumn{2}{|c|}{ Unstandardized Coefficients } & $\begin{array}{l}\text { Standardized } \\
\text { Coefficients }\end{array}$ & \multirow[b]{2}{*}{$\mathrm{t}$} & \multirow[b]{2}{*}{ Sig. } \\
\hline & & B & Std. Error & Beta & & \\
\hline \multirow[t]{6}{*}{1} & (Constant) & .045 & .122 & & .364 & .717 \\
\hline & $x 1$ & .107 & .030 & .091 & 3.550 & .001 \\
\hline & $x 2$ & .179 & .037 & .178 & 4.785 & .000 \\
\hline & $x 3$ & .163 & .039 & .165 & 4.202 & .000 \\
\hline & $x 4$ & .103 & .031 & .100 & 3.320 & .001 \\
\hline & z & .469 & .051 & .476 & 9.199 & .000 \\
\hline
\end{tabular}

a. Dependent Variable: y

Sumber: Hasil Penelitian, diolah (2020)

Adapun penjelasan uraian dari persamaan regresi tersebut adalah:

$$
\mathrm{Y}=0,045+0,107\left(\mathrm{X}_{1}\right)+0,179\left(\mathrm{X}_{2}\right)+0,163\left(\mathrm{X}_{3}\right)+0,103\left(\mathrm{X}_{4}\right)+0,469(\mathrm{Z})+\mathrm{e}
$$

Dengan bunyi persamaan sebagai berikut:

a. Persamaan Regresi Sistem Perpajakan $\left(\mathrm{X}_{1}\right)$

Koefesien regresi variabel sistem perpajakan $\left(\mathrm{X}_{1}\right)$ sebesar 0,107 artinya jika sistem perpajakan $\left(\mathrm{X}_{1}\right)$ mengalami kenaikan sebesar $1 \%$, maka keputusan membayar pajak kendaraan bermotor pada Samsat Banjarmasin I akan mengalami kenaikan sebesar $10,7 \%$.

b. Persamaan Regresi Pelayanan perpajakan $\left(\mathrm{X}_{2}\right)$

Koefesien regresi variabel Pelayanan perpajakan $\left(\mathrm{X}_{2}\right)$ sebesar 0,179 artinya jika Pelayanan perpajakan $\left(\mathrm{X}_{2}\right)$ mengalami kenaikan sebesar $1 \%$, maka keputusan membayar pajak kendaraan bermotor pada Samsat Banjarmasin I akan mengalami kenaikan sebesar $17,9 \%$.

c. Persamaan Regresi Sanksi perpajakan $\left(\mathrm{X}_{3}\right)$

Koefesien regresi variabel sanksi perpajakan $\left(\mathrm{X}_{3}\right)$ sebesar 0,163 artinya jika sanksi perpajakan $\left(\mathrm{X}_{3}\right)$ mengalami kenaikan sebesar $1 \%$, maka keputusan membayar pajak kendaraan bermotor pada Samsat Banjarmasin I akan mengalami kenaikan sebesar $16,3 \%$.

d. Persamaan Regresi Kesadaran Wajib Pajak $\left(\mathrm{X}_{4}\right)$

Koefesien regresi variabel sanksi perpajakan $\left(\mathrm{X}_{4}\right)$ sebesar 0,103 artinya jika sanksi perpajakan $\left(\mathrm{X}_{4}\right)$ mengalami kenaikan sebesar $1 \%$, maka keputusan 
membayar pajak kendaraan bermotor pada Samsat Banjarmasin I akan mengalami kenaikan sebesar $10,3 \%$.

e. Persamaan Regresi Kepatuhan (Z)

Koefesien regresi variabel kepatuhan (Z) sebesar 0,469 artinya jika kepatuhan (Z) mengalami kenaikan sebesar 1\%, maka keputusan membayar pajak kendaraan bermotor pada Samsat Banjarmasin I akan mengalami kenaikan sebesar $46,9 \%$.

\section{Uji Hipotesis}

a. Pengaruh Sistem Perpajakan, Pelayanan Perpajakan, Sanksi Perpajakan dan Kesadaran Wajib Pajak secara Simultan terhadap kepatuhan dan keputusan membayar pajak kendaraan bermotor pada Samsat Banjarmasin I (Uji F)

Adapun hasil analisis pengaruh Sistem Perpajakan, Pelayanan Perpajakan, Sanksi Perpajakan dan Kesadaran Wajib Pajak secara simultan terhadap kepatuhan membayar pajak kendaraan bermotor pada Samsat Banjarmasin I dapat dilihat pada tabel berikut.

Tabel 9. Hasil Uji F ANOVA $^{\text {b }}$

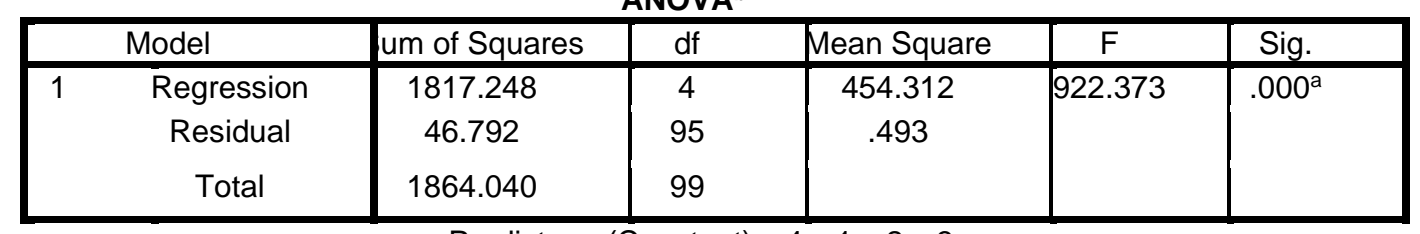

a. Predictors: (Constant), $x 4, x 1, \times 2, \times 3$

$$
\text { b. Dependent Variable: } z
$$

Sumber: Hasil Penelitian, diolah (2020)

Hasil analisa menunjukkan bahwa H0 ditolak dan Ha diterima, ini berarti bahwa pengaruh Sistem Perpajakan, Pelayanan Perpajakan, Sanksi Perpajakan dan Kesadaran Wajib Pajak secara simultan terhadap kepatuhan membayar pajak kendaraan bermotor pada Samsat Banjarmasin I (Sig. $=0,000<0,05)$.

Sedangkan hasil analisis pengaruh Sistem Perpajakan, Pelayanan Perpajakan, Sanksi Perpajakan dan Kesadaran Wajib Pajak secara simultan terhadap keputusan membayar pajak kendaraan bermotor pada Samsat Banjarmasin I dapat dilihat pada tabel berikut.

\section{Tabel 10. Hasil Uji F} ANOVA $^{\mathrm{b}}$

\begin{tabular}{|c|c|c|c|c|c|}
\hline Model & um of Squares & $\mathrm{df}$ & Mean Square & $\mathrm{F}$ & Sig. \\
\hline Regression & 1798.735 & 5 & 359.747 & 2952.207 & $.000^{\mathrm{a}}$ \\
Residual & 11.455 & 94 & .122 & & \\
Total & 1810.190 & 99 & & & \\
\hline
\end{tabular}

$$
\text { b. Dependent Variable: } y
$$

Sumber: Hasil Penelitian, diolah (2020)

Hasil analisa menunjukkan bahwa H0 ditolak dan Ha diterima, ini berarti bahwa pengaruh Sistem Perpajakan, Pelayanan Perpajakan, Sanksi Perpajakan dan Kesadaran Wajib Pajak secara simultan terhadap keputusan membayar pajak kendaraan bermotor pada Samsat Banjarmasin I (Sig. $=0,000<0,05)$. 
b. Pengaruh Sistem Perpajakan, Pelayanan Perpajakan, Sanksi Perpajakan dan Kesadaran Wajib Pajak secara Parsial terhadap Kepatuhan dan Keputusan Membayar Pajak Kendaraan Bermotor pada Samsat Banjarmasin I (Uji t)

Adapun hasil analisis pengaruh Sistem Perpajakan, Pelayanan Perpajakan, Sanksi Perpajakan dan Kesadaran Wajib Pajak secara parsial terhadap kepatuhan membayar pajak kendaraan bermotor pada Samsat Banjarmasin I dapat dilihat pada tabel berikut ini:

Coefficients $^{\mathrm{a}}$

Tabel 11. Hasil Uji t-tes

\begin{tabular}{|c|c|c|c|c|c|c|}
\hline \multirow{2}{*}{\multicolumn{2}{|c|}{ Model }} & \multicolumn{2}{|c|}{ Unstandardized Coefficients } & $\begin{array}{l}\text { Standardized } \\
\text { Coefficients }\end{array}$ & \multirow[b]{2}{*}{$\mathrm{t}$} & \multirow[b]{2}{*}{ Sig. } \\
\hline & & $\mathrm{B}$ & Std. Error & Beta & & \\
\hline \multirow[t]{5}{*}{1} & (Constant) & -.227 & .245 & & -.925 & .357 \\
\hline & $x 1$ & .192 & .057 & .162 & 3.349 & .001 \\
\hline & $x 2$ & .336 & .067 & .330 & 5.036 & .000 \\
\hline & $x 3$ & .324 & .070 & .323 & 4.602 & .000 \\
\hline & $x 4$ & .201 & .059 & .193 & 3.416 & .001 \\
\hline
\end{tabular}

a. Dependent Variable: $z$

Sumber: Hasil Penelitian, diolah (2020)

Berdasarkan tabel tersebut dapat diketahui bahwa:

1) Pengaruh Sistem perpajakan terhadap kepatuhan membayar pajak kendaraan bermotor pada Samsat Banjarmasin I

Nilai Signifikan dari variabel bebas sistem perpajakan $\left(\mathrm{X}_{1}\right)$ sebesar 0,001 $<0,05$ menunjukkan ada pengaruh signifikan antara variabel Sistem perpajakan $\left(\mathrm{X}_{1}\right)$ terhadap kepatuhan membayar pajak kendaraan bermotor pada Samsat Banjarmasin I (Z).

2) Pengaruh Pelayanan perpajakan terhadap kepatuhan membayar pajak kendaraan bermotor pada Samsat Banjarmasin I

Nilai Signifikan dari variabel bebas Pelayanan perpajakan $\left(\mathrm{X}_{2}\right)$ sebesar $0,000<$ 0,05 menunjukkan ada pengaruh signifikan antara variabel Pelayanan perpajakan $\left(\mathrm{X}_{2}\right)$ terhadap kepatuhan membayar pajak kendaraan bermotor pada Samsat Banjarmasin I (Z).

3) Pengaruh Sanksi perpajakan terhadap kepatuhan membayar pajak kendaraan bermotor pada Samsat Banjarmasin I

Nilai Signifikan dari variabel bebas Sanksi perpajakan $\left(\mathrm{X}_{3}\right)$ sebesar $0,000<0,05$ menunjukkan bahwa Sanksi perpajakan $\left(\mathrm{X}_{3}\right)$ memiliki pengaruh signifikan terhadap kepatuhan membayar pajak kendaraan bermotor pada Samsat Banjarmasin I (Z).

4) Pengaruh kesadaran wajib pajak terhadap kepatuhan membayar pajak kendaraan bermotor pada Samsat Banjarmasin I

Nilai Signifikan dari variabel bebas kesadaran wajib pajak $\left(\mathrm{X}_{4}\right)$ sebesar $0,000<$ 0,05 menunjukkan bahwa kesadaran wajib pajak $\left(\mathrm{X}_{4}\right)$ memiliki pengaruh signifikan terhadap kepatuhan membayar pajak kendaraan bermotor pada Samsat Banjarmasin I (Z).

Sedangkan hasil analisis pengaruh sistem perpajakan, pelayanan perpajakan, sanksi perpajakan, dan kepatuhan membayar pajak secara parsial 
terhadap keputusan membayar pajak kendaraan bermotor pada Samsat Banjarmasin I dapat dilihat pada tabel berikut ini:

Tabel 12. Hasil Uji t-tes

Coefficients $^{a}$

\begin{tabular}{|c|c|c|c|c|c|c|}
\hline \multirow{2}{*}{\multicolumn{2}{|c|}{ Model }} & \multicolumn{2}{|c|}{ Unstandardized Coefficients } & $\begin{array}{l}\text { Standardized } \\
\text { Coefficients }\end{array}$ & \multirow[b]{2}{*}{$\mathrm{t}$} & \multirow[b]{2}{*}{ Sig. } \\
\hline & & $B$ & Std. Error & Beta & & \\
\hline \multirow[t]{6}{*}{1} & (Constant) & .045 & .122 & & .364 & .717 \\
\hline & $\mathrm{x} 1$ & .107 & .030 & .091 & 3.550 & .001 \\
\hline & $x 2$ & .179 & .037 & .178 & 4.785 & .000 \\
\hline & $x 3$ & .163 & .039 & .165 & 4.202 & .000 \\
\hline & $x 4$ & .103 & .031 & .100 & 3.320 & .001 \\
\hline & z & .469 & .051 & .476 & 9.199 & .000 \\
\hline
\end{tabular}

a. Dependent Variable: $y$

Sumber: Hasil Penelitian, diolah (2020)

Berdasarkan tabel tersebut dapat diketahui bahwa:

1) Pengaruh Sistem perpajakan terhadap keputusan membayar pajak kendaraan bermotor pada Samsat Banjarmasin I

Nilai Signifikan dari variabel bebas sistem perpajakan $\left(\mathrm{X}_{1}\right)$ sebesar $0,001<0,05$ menunjukkan ada pengaruh signifikan antara variabel Sistem perpajakan $\left(\mathrm{X}_{1}\right)$ terhadap keputusan membayar pajak kendaraan bermotor pada Samsat Banjarmasin I (Y).

2) Pengaruh Pelayanan perpajakan terhadap keputusan membayar pajak kendaraan bermotor pada Samsat Banjarmasin I

Nilai Signifikan dari variabel bebas Pelayanan perpajakan $\left(\mathrm{X}_{2}\right)$ sebesar $0,000<$ 0,05 menunjukkan ada pengaruh signifikan antara variabel Pelayanan perpajakan $\left(\mathrm{X}_{2}\right)$ terhadap keputusan membayar pajak kendaraan bermotor pada Samsat Banjarmasin I (Y).

3) Pengaruh Sanksi perpajakan terhadap keputusan membayar pajak kendaraan bermotor pada Samsat Banjarmasin I

Nilai Signifikan dari variabel bebas Sanksi perpajakan $\left(\mathrm{X}_{3}\right)$ sebesar $0,000<0,05$ menunjukkan bahwa Sanksi perpajakan $\left(\mathrm{X}_{3}\right)$ memiliki pengaruh signifikan terhadap keputusan membayar pajak kendaraan bermotor pada Samsat Banjarmasin I (Y).

4) Pengaruh kesadaran wajib pajak terhadap keputusan membayar pajak kendaraan bermotor pada Samsat Banjarmasin I

Nilai Signifikan dari variabel bebas kesadaran wajib pajak $\left(\mathrm{X}_{4}\right)$ sebesar $0,001<$ 0,05 menunjukkan bahwa kesadaran wajib pajak $\left(\mathrm{X}_{4}\right)$ memiliki pengaruh signifikan terhadap keputusan membayar pajak kendaraan bermotor pada Samsat Banjarmasin I (Y).

5) Pengaruh kepatuhan terhadap keputusan membayar pajak kendaraan bermotor pada Samsat Banjarmasin I

Nilai Signifikan dari variabel bebas kepatuhan $(Z)$ sebesar $0,000<0,05$ menunjukkan bahwa kepatuhan (Z) memiliki pengaruh signifikan terhadap keputusan membayar pajak kendaraan bermotor pada Samsat Banjarmasin I (Y). 
c. Variabel yang Berpengaruh Dominan terhadap kepatuhan dan keptusan membayar pajak kendaraan bermotor pada Samsat Banjarmasin I

Berdasarkan pada Tabel 7 dan Tabel 8 tersebut di atas, dapat diketahui bahwa variabel pelayanan perpajakan $\left(\mathrm{X}_{2}\right)$ memiliki pengaruh dominan terhadap kepatuhan membayar pajak kendaraan bermotor pada Samsat Banjarmasin I (Y) dan kepatuhan $(Z)$ memiliki pengaruh dominan terhadap keputusan membayar pajak kendaraan bermotor pada Samsat Banjarmasin I (Y).

\section{Pembahasan}

Pengaruh Sistem Perpajakan, Pelayanan Perpajakan, Sanksi Perpajakan dan Kesadaran Wajib Pajak secara Simultan terhadap Kepatuhan dan Keputusan Membayar Pajak Kendaraan Bermotor pada Samsat Banjarmasin I (Uji F)

Hasil analisis menunjukkan bahwa Sistem Perpajakan, Pelayanan Perpajakan, Sanksi Perpajakan dan Kesadaran Wajib Pajak secara simultan terhadap kepatuhan dan keputusan membayar pajak kendaraan bermotor pada Samsat Banjarmasin I (Sig. $=0,000<0,05)$. Hal tersebut membuktikan bahwa peranan dari ekseluruhan variabel besab berpen sangat penting terhadap kepatuhan dan keputusan masyarakat untuk membayarkan pajak kendaraan bermotor yang dimilikinya.

Pengaruh Sistem Perpajakan, Pelayanan Perpajakan, Sanksi Perpajakan dan KEsadaran Wajib Pajak secara Parsial terhadap Kepatuhan dan Keputusan Membayar Pajak Kendaraan Bermotor pada Samsat Banjarmasin I (Uji t)

a. Pengaruh Sistem Perpajakan terhadap Kepatuhan dan Keputusan Membayar Pajak Kendaraan Bermotor pada Samsat Banjarmasin I

Ada pengaruh signifikan antara variabel sistem perpajakan $\left(\mathrm{X}_{1}\right)$ terhadap kepatuhan

(Z) dan keputusan membayar pajak kendaraan bermotor pada Samsat Banjarmasin I

(Y). sistem perpajakan khususnya mengenai pembayaran pajak kendaraan bermotor di Banjarmasin sudah cukup mudah karena bisa melalui berbagai cara seperti layanan Samsat Keliling (SAMKEL), Drive Thru, Jemput Antar dan Samsat Corner Duta Mall yang melayani pembayaran secara online dan lain sebagainya. Namun sosialisasi mengenai sistem perpajakan masih kurang karena hal tersebut terbukti sebagian masyarakat masih belum mengetahui baik mengenai jadwal, cara dan prosedur pembayaran pajak kendaraan bermotor.

b. Pengaruh Pelayanan Perpajakan terhadap Kepatuhan dan Keputusan Membayar Pajak Kendaraan Bermotor pada Samsat Banjarmasin I

Ada pengaruh signifikan antara variabel pelayanan perpajakan $\left(\mathrm{X}_{2}\right)$ terhadap kepatuhan (Z) dan keputusan membayar pajak kendaraan bermotor pada Samsat Banjarmasin I (Y). agar mampu meningkatkan kepatuhan dan peputusan pembayaran pajak kendaraan bermotor, maka salah satu cara yang dapat dilakukan oleh Samsat Banjarmasin I dengan emmperbaiki sistem pelayanan yang diberikan masyarakat seperti peningkatan jumlah pegawai yang melayani masyarakat, menajmbah jumlah armada layanan Samsat Keliling (SAMKEL), meningkatkan kenyamanan fasilitas penunjang dan meningkatkan kompetensi para pegawainya.

c. Pengaruh Sanksi Perpajakan terhadap Kepatuhan dan Keputusan Membayar Pajak Kendaraan Bermotor pada Samsat Banjarmasin I 
Ada pengaruh signifikan antara variabel sanksi perpajakan $\left(X_{3}\right)$ terhadap kepatuhan (Z) dan keputusan membayar pajak kendaraan bermotor pada Samsat Banjarmasin I (Y). Sebagian masyarakat masih banyak yang menunda untuk melakukan pemabayaran pajak kendaraan bermotor selain diakibatkan kurang perhatian dan disiplin masyarakat dalam membayar pajak, hal tersebut juga diakibatkan pendapatan pereskonomian masyarakat yang masih rendah. Adanya upaya dari pemerintah kota Banjarmasin seperti penghapusan pajak sudah cukup membantu masyarakat untuk melakukan pembayaran pajak kendaraan bermotor, namun hal tersebut masih belum mampu meningkatkan kepatuhan masyarakat untuk membayar pajak tepat waktu, maka pemerintah juga perlu menerapkan tindakan sanksi tegas bagi amsyarakat yang tetap lalai dan menunggak pembayaran pajak kendaraan bermotor.

d. Pengaruh Kesadaran Wajib Pajak terhadap Kepatuhan dan Keputusan Membayar Pajak Kendaraan Bermotor pada Samsat Banjarmasin I

Ada pengaruh signifikan antara variabel kesadaran wajib pajak $\left(\mathrm{X}_{3}\right)$ terhadap kepatuhan (Z) dan keputusan membayar pajak kendaraan bermotor pada Samsat Banjarmasin I (Y). Kurangnya kesadaran masyarakat untuk membayar pajak tepat waktu berpotensi mengakibatkan penurunan pendapatan daerah, sehingga pemerintah harus turun tangan guna meningkatkan kesadaran masyarakat untuk membayar pajak tepat waktu selain untuk menghindari denda/sanksi, pembayaran pajak kendaraan tepat waktu juga berguna untuk meningkatkan kesejahteraan dan pembangunan kemajuan di daerah.

e. Pengaruh Kepatuhan terhadap Keputusan Membayar Pajak Kendaraan Bermotor pada Samsat Banjarmasin I

Ada pengaruh signifikan antara variabel kepatuhan (Z) terhadap keputusan membayar pajak kendaraan bermotor pada Samsat Banjarmasin I (Y). Sebagian masyarakat banyak yang dengan sengaja menunda pembayaran pajak dengan alasan menunggu adanya penghapusan sanksi pajak dan lalai terhadap kewajiban membayar pajaknya. Hal ini diakibatkan kurang tegasnya sanksi yang diberikan ataupun akibat kemudahan masyarakt untuk emmiliki kendaraan bermotor melalui dana pinjaman dengan syarat yang mudah mengakibatkan masyarakat tidak mampu menyesuaikan antara keadaan finansial dengan kemampuannya unukt membayar pajak kendaraan bermotor yang dimilikinya.

1. Variabel yang Berpengaruh Dominan terhadap Kepatuhan dan Keputusan Membayar Pajak Kendaraan Bermotor pada Samsat Banjarmasin I

Variabel pelayanan perpajakan $\left(\mathrm{X}_{2}\right)$ memiliki pengaruh dominan terhadap kepatuhan membayar pajak kendaraan bermotor pada Samsat Banjarmasin I (Y), dengan meningkatkan pelayanan kepada masyarakat diharapkan masyarakat lebih taat dan patuh dalam membayar pajak, sedangkan kepatuhan (Z) memiliki pengaruh dominan terhadap keputusan membayar pajak kendaraan bermotor pada Samsat Banjarmasin I (Y) hal tersebut memiliki makna bahwa apabila masyarakat patuh untuk membayar pajak tepat waktu, maka mereka akan membayar pajak sesuai dengan ketetapan yang telah ditetapkan oleh pemerintah dan undangundang. 


\section{DAFTAR PUSTAKA}

Abdul Rahman. 2016. Panduan Pelaksanaan Administrasi Perpajakan Untuk Karyawan, Pelaku Bisnis dan Perusahaan. Bandung: Nuansa.

Adriani, P.J.A. 2018. Pengantar Ilmu Hukum Pajak. Jakarta: Gramedia.

Aristanti Widyaningsih, A. 2018. Hukum Pajak dan Perpajakan. Bandung: Alfabeta.

Diana Sari. 2018. Konsep Dasar Perpajakan. Bandung: Refika Aditama.

Erly Suandy. 2018. Perencanaan Pajak. Jakarta: Salemba Empat.

Mardiasmo. 2018. Perpajakan. Yogyakarta: Andi.

Siti Kurnia Rahayu. 2016. Perpajakan Indonesia, Yogyakarta: Graha Ilmu.

Siti Resmi. 2019. Perpajakan Teori dan Kasus. Jakarta: Salemba Empat.

Soemarso. 2016. Asas dan Dasar Perpajakan I. Bandung: PT. Refika

Waluyo. 2016. Perpajakan Indonesia. Jakarta.: Salemba Empat. 